\title{
Modelling effect of valuable resources on franchise outlet performance: Dynamic sensing capability as mediator
}

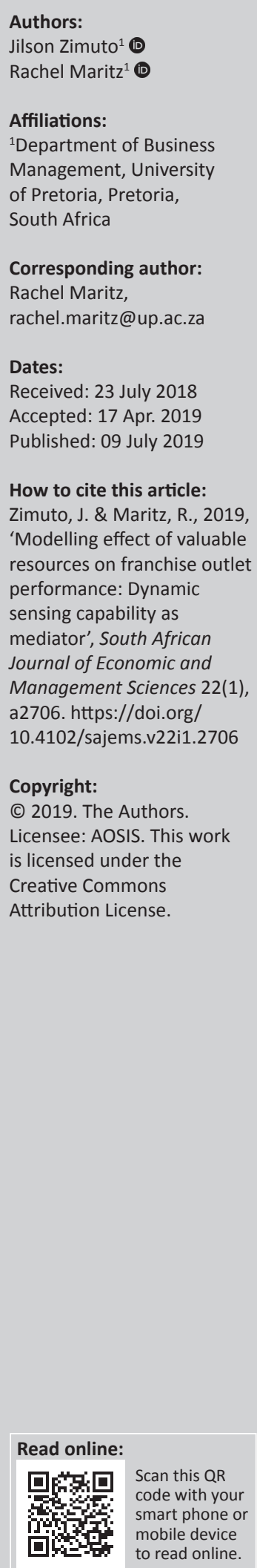

Background: Competitive advantage and superior firm performance depend on resources and dynamic capabilities.

Aim: This study aims to provide insight into the franchising industry where research on the value-dynamic sensing capability-performance relationship as part of the resource-based theory (RBT) seems to be novel. Drawing on the RBT, this study examines how valuable resources and dynamic sensing capability impact franchise outlet performance.

Setting: Based on a cross-sectional design, a sample of 224 South African franchise outlet managers and owner-operators in the fast food and retailing categories was surveyed.

Methods: Hypotheses were tested using a single-level structural equation model for value, dynamic sensing capability and performance.

Results: The results contribute to research on RBT in the context of franchises by providing support for the assumption that firm resources and capabilities improve performance.

Conclusion: The findings are expected to provide a strong base from which franchise managers and owner-operators can strategise for competitive advantage in an emerging economy like South Africa.

Keywords: Resource-based theory; resource-based view; strategy; dynamic sensing capability; performance; franchises.

\section{Introduction}

The debate over the ability of dynamic capabilities (Teece, Pisano \& Shuen 1997:509) to align and realign resources (Eisenhardt \& Martin 2000:1106) in a turbulent environment for competitive advantage is rife in research. The rationale is that the resource-based view (RBV) of the firm has not adequately explained how and why certain firms have a competitive advantage (Eisenhardt \& Martin 2000:1106) and dynamic capabilities by which firm managers integrate, build, and reconfigure resources (Teece et al. 1997:516) to become the source of sustained competitive advantage. The RBV has matured into the resource-based theory (RBT) and still has theoretical relevance and applicability in today's competitive strategy environment and is widely acknowledged as one of the most prominent and powerful theories for describing, explaining, and predicting organisational relationships (Barney, Ketchen \& Wright 2011:1300). Barney et al. (2011:1309) remark that further studies on the RBT should also take into account the environment in which individuals find themselves and test the relationships as they are conditioned by context. This study therefore contributes to literature by examining relationships within the proven RBT framework but focusing on the specific context of franchises in an emerging economy.

From previous theoretical and empirical studies (for example, Akremi, Perrigot \& Piot-Lepetit 2015:145; Gillis, Combs \& Ketchen 2013:449; Mumdziev \& Windsperger 2011:449) it is clear that little has been done in the context of franchising. Findings from the cited studies all support the positive impact of resources in franchising. Akremi et al. (2015:145) found that dynamic capabilities (for example, training and experience) are some of the independent variables that positively impact on performance of franchised chains. Mumdziev and Windsperger (2011:449) found that innovation assets affect decision rights allocations. Other scholars have established and emphasised the characteristics of a firm's resources and capabilities as the source of the performance differences among firms. For the purposes of this study, RBT, which evolved as a clear framework from the RBV of the firm, and the literature on dynamic capabilities are adopted to provide an empirical analysis of the variables contained in the RBV and their influence on South African franchise outlet performance. The aim of the study is to provide insight into 
the effect of resources that are deemed valuable on firm performance and at the same time to explore the influence of capabilities on achieving firm performance in the franchise environment. Drawing on a comprehensive literature review it became clear that the relationship and influence of resources on the value-dynamic sensing capabilityperformance relationship as part of the RBT are novel in RBT research. Using the RBT as a launching pad the study examines how valuable resources and dynamic sensing capability impact franchise outlet performance.

South Africa boasts over 600 franchised brands and about 39000 franchised outlets (Franchise Association of South Africa [FASA] 2016:15). Wingrove and Urban (2017:1-8) argue that researching franchised fast food restaurant brands is important for an emerging market context such as South Africa, especially considering their sizeable influence on the economy. In addition, KPMG (2016) reports that franchising industry growth reflects over 31050 franchise outlets in South Africa, employing 323519 people nationally (KPMG 2016:2). Of these $323519,34 \%$ are employed in retailing and direct marketing while $27 \%$ are in fast foods and restaurants (FASA 2016:16). In addition, Schwarzer (2017:5) reiterates 'similarly, when franchising economic output is measured as a share of a country's overall gross domestic product (GDP), South Africa emerges in the top five - with $11.5 \%$ of its GDP generated by franchises'. To this GDP, fast foods and restaurants, inter alia, generated annual turnover of R52.2 million, while retailing contributed R8.9 million (FASA 2016:13). Wingrove and Urban (2017:2) posit that research needs to emphasise how franchising impacts organisational performance and drives growth. Hence franchising in South Africa becomes a fertile ground for academic research because both the franchisor and the franchisee resources play a major role in the performance of their outlets.

Following assumptions of the RBT, superior performance of the franchises is attributed to the resources of the franchisor and resources of the franchisee. Resources may be tangible or intangible. Financial, physical, organisational, intellectual and human resources possessed by a franchise firm are expected to be valuable, rare, inimitable and non-substitutable (VRIN). VRIN resource characteristics (Barney 1991:99) of RBV of the firm are the empirical drivers of firm performance if used in combination (Penrose 1959:25).

\section{Underlying theory}

RBV of the firm, which has evolved into a theory (Barney 1991:99), postulates a firm as a bundle of resources (Penrose 1959), and the resources are controlled by the firm (Amit \& Schoemaker 1993:35). Building on the RBV of the firm assumptions, Barney (1991) published his seminal work clearly defining the RBT. However, studies from other scholars (for example, Afuah 2013:1; Eisenhardt \& Martin 2000:1105; Henderson \& Cockburn 1994:63; Parmigiani \& Holloway 2011:457) still refer to this theory as the RBV of the firm. This article builds on the premise of the RBT which again crystallised from the RBV. As such the article will explain the premises for both the RBV and the RBT. Barney et al. (2011:1303) postulate that the RBT has reached a level of maturity as a theory, where scholars are increasingly using the term resource-based theory instead of resource-based view. They argue that this indicates that resource-based research has reached a level of precision and sophistication to such an extent that it more closely resembles a theory than a view. One prominent spin-off perspective from this theory, the RBT, is that of dynamic capabilities (Barney et al. 2011:1303; Teece et al. 1997). It is also this dynamic capabilities perspective that this article explores in the relationship between value and performance, where the dynamic sensing capability is examined as a mediator variable between valuable resources and performance.

According to the RBV, firms are expected to have capabilities or capacities to deploy resources (Amit \& Schoemaker 1993:35). These resources and capabilities are explained as heterogeneously distributed among firms and imperfectly mobile (Barney 1991:99). Such assumptions propound the existence of differences in firm resource endowments and these differences persist over time (Barney 1991:101). The RBV of the firm studies hypothesise that firms that possess and exploit resources and capabilities that are valuable and rare attain a competitive advantage. Second, if these resources and capabilities are also both inimitable and nonsubstitutable, the firm will sustain this advantage, and they will enable the firm to improve its performance (Amit \& Schoemaker 1993:33; Barney 1991:99; Eisenhardt \& Martin 2000:1105; Henderson \& Cockburn 1994:63; Powell 2001:875). However, Barney (1995:56) argues that for a firm to fully realise this potential, it must also be organised to exploit its resources and capabilities. This implies that resources and capabilities are vital for a firm if organised, deployed and implemented.

In addition, other scholars (Teece et al. 1997) extended the RBV with the dynamic-capability view (DCV) to evaluate the influences of dynamic markets (Helfat \& Peteraf 2015:831). Teece et al. (1997:509) regard dynamic capabilities as a transformer for converting resources into improved performance. However, the empirical research to examine the relationships between all the resource characteristics, dynamic capabilities and performance has not been given much attention in the literature. Hence there is very little empirical research operationalising value, rarity, inimitability and organisation (VRIO). Conversely, VRIN has received considerable attention, although the studies are still few. For example, Lin and $\mathrm{Wu}$ (2014) investigated VRIN but did not operationalise it as individual characteristics; Morgan, Vorhies and Schlegelmilch (2006) used only inimitability and non-substitutability, while Newbert (2008) employed only rareness and value. This study addresses the gap by assessing how individual value resource characteristics can be converted into performance through dynamic sensing capability. Theoretical and empirical suggestions for strategic decisions regarding resources and dynamic capabilities are provided. 


\section{Resource-based view of the firm and the franchising industry}

There is now a move toward a RBV of franchising (Gillis et al. 2013:451) and this is supported by franchising research called the symbiosis perspective (Perryman \& Combs 2012:368), which explains resource effects on franchising. Although several empirical studies have examined the performance implications of governance decisions and firms' resource characteristics in the franchising context (Barthélemy 2008:1451; Combs \& Ketchen 1999:196; Perdreau, Le Nadant \& Cliquet 2015:121; Yin \& Zajac 2004:365), this may not be a true reflection of the franchising sector of VRIN resources-dynamic capabilities-performance relationships in South Africa. That is why Gillis et al. (2013:449) have offered preliminary evidence that the RBT has merit as a complementary explanation for franchising.

The above studies are evidence that $\mathrm{RBV} / \mathrm{RBT}$ is vital in explaining franchising because it can be assumed also that the franchisor/franchisee has specific resources and capabilities that can result in competitive advantage. The higher these resources and capabilities of the franchisor/franchisee, the higher the rentgenerating potential of the resources (Combs et al. 2011). The use of RBT would allow more in-depth explanation regarding resources, organisational capabilities and competitive advantage of franchise chains. Through RBT, it is possible to make sound decisions because FASA $(2016: 11,14)$ argues that it takes a long period before a new franchisee breaks even and that there are also challenges of customer satisfaction and knowledge of the business. On this basis, this study proposed to complement existing studies on franchising by the modelling of franchise chain resources (financial, human, intellectual, organisational and physical) effects on its performance (market share, growth in market share, sales volume, and growth in sales volume) through dynamic sensing capability.

Furthermore, dynamic capabilities have emerged as an approach that is useful to help us understand why some chains are more likely to drive performance (Akremi et al. 2015:145). The dynamic capabilities approach is an offshoot of the resource-based view (Barney 1991:99; Eisenhardt \& Martin 2000:1105) and the ability of a firm to 'integrate, build, and reconfigure internal and external competencies to address rapidly changing environments' (Teece et al. 1997:516) is a critical source of superior performance. This approach is a relevant theoretical lens for deepening our understanding of factors that influence performance in franchising (Akremi et al. 2015:146). Dynamic capabilities demonstrate that the manipulation of resources, in particular knowledge resources, is especially critical in the franchising context and emphasise the importance of replication and learning (Teece et al. 1997:516; Zollo \& Winter 2002:339). For example, hotels or restaurants that can integrate and reconfigure are probably going to experience superior performance.

\section{Conceptual model and hypothesis development}

Hypotheses were developed about the effects of valuable resources on franchise outlet performance as mediated with

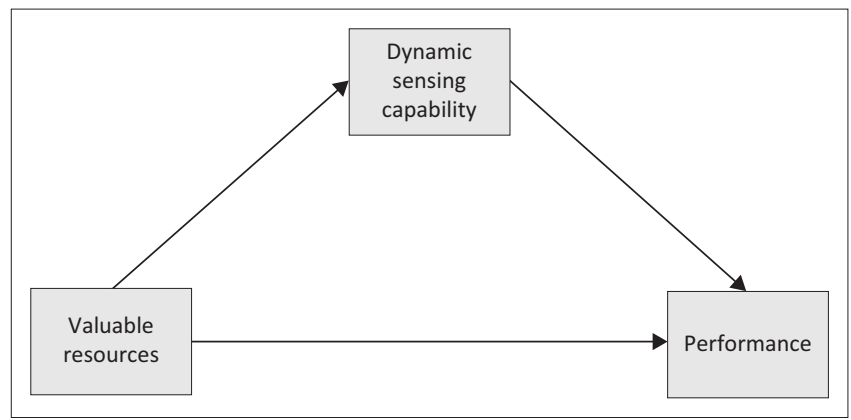

FIGURE 1: Conceptual model to test valuable resources-dynamic sensing capability-performance relationship.

dynamic sensing capability (Figure 1). First, the focus was on value (Barney 1991:106; Newbert 2008) as an independent construct which was hypothesised to have direct effects on dynamic sensing capability. Second, the hypothesis tested the mediating role of the dynamic sensing capability between valuable resources and performance. This was premised on the fact that performance differentials are produced by resource heterogeneity among competing firms (Barney 1991:103; Mol \& Wijnberg 2011:77). Performance (Morgan et al. 2006:627; Wilden \& Gudergan 2015:190) as a dependent variable emphasised sales volume, growth in sales volume, market share and growth in market share (Newbert 2008:766).

\section{Valuable resources and franchise outlet performance}

Resources are by definition the source of firm performance (Andersen 2011:88). Also, resources are always a prerequisite for all firms to function, and all other steps to achieving high performance are dependent on the possession of resources (Andersen 2011:89). No firm can enjoy competitive advantage without valuable resources. Considering how fast food restaurants were created to expedite the delivery of food to customers in a hurry, technology has stepped forward to make that service even speedier. Digital displays furthermore allow outlets to change their menus efficiently and when restaurants add innovative technology to the menu, it leads to better service and food options. It shows that IT resources are and can be used to improve firm performance (Cohen \& Oslen 2013:246). This postulates the potential of resources to influence customer perceptions of value.

Mol and Wijnberg (2011:81) argue that resources need to be valuable first before other strategic considerations can be made with regard to their deployment. They explain three dimensions of resource value which they consider as paramount in facilitating sustained performance. The three dimensions of resource value are (1) by either allowing a firm to enter the selection system or prevent its rivals from doing so, (2) by creating product characteristics that have value according to product selectors, and (3) by either allowing a firm to engage in competitive imitation or preventing its rivals from doing so (Mol \& Wijnberg 2011:79). The first dimension suggests that for the competitive advantage of the firm to be generated the value of the resources should be analysed with reference to the competitive process taking 
place in the product market (Bowman \& Ambrosini 2001:501). Other preceding dimensions describe competitive processes in terms of the selectors who contribute to value (Gemser \& Wijnberg 2001:563; Priem 2007:219). For example, when buying a new car tyre, consumers often rely on evaluations by experts, such as product critics who rate tyres (Bridgestone, Dunlop, Firestone etc.) on price, durability or usage. Santos and Eisenhardt (2005:497) argue that organisational boundaries should be set at the point that maximises the value of the firm's resource portfolio.

The value of some resources is more difficult to determine than others (Mol \& Wijnberg 2011:85). Understanding the value of resources in terms of their functionality in the product market helps address this issue and can be used to assess the logic underlying complex or bundled resources (Denrell, Fang \& Winter 2003:977; Lippman \& Rumelt 2003:903; Wernerfelt 1984:393). Further, Mol and Wijnberg (2011:88) propound that if it becomes easy to identify the value of superior resources, the sustainability of the organisational performance is jeopardised. On the other hand, if managers are not able to adequately estimate the value of resources and reward them accordingly, their capacity to select and deploy them effectively is significantly hampered and hence organisational performance suffers (Makadok 2001:387). Therefore, managers are encouraged to have an appreciation of resource value from competitors, so that they are provided with enhanced opportunities for better performance.

Managers create value by developing resource bundles that enable firms to undertake novel and appropriate tasks, services, jobs, products, processes, or other combinations perceived to be of value in producing greater utility or lower unit costs in use (Lepak, Smith \& Taylor 2007:183). Resource bundles represent unique combinations of resources that enable firms to take advantage of specific market opportunities when effectively deployed (Peteraf \& Barney 2003:309). Thus, firms realise a performance advantage when managers synchronise the resource management processes within and between interdependent bundles such that organisational performance is optimised (Holcomb, Holmes \& Connelly 2009:458). This explains the opinion that a firm's management and synchronisation of resources promote organisational performance.

In the franchising industry literature, the proportion franchised is influenced by efforts to organise franchisorowned and relational strategic assets so that their value can be best leveraged to meet key strategic goals (Gillis et al. 2013:449). Franchisees are granted the right to use intellectual capital (Watson et al. 2005:25) which refers to intangible resources (knowledge-based components) and encompasses all the information, experience, skills, structures, culture, and relationships of a firm that collectively help to create wealth (Wexler 2002:393). For example, a franchise chain with a strong brand reputation is well known and respected among consumers (Davis \& Mentzer 2008:435). Barthélemy (2008:1451) showed that franchising networks with a valuable brand name and tacit business practices tend to perform better when they have a low proportion of franchised outlets. However, performance issues have received little attention in the franchising context (Perdreau et al. 2015:123).

Hence it can be hypothesised that:

$\mathbf{H}_{1}$ : The value of the resources that a franchise outlet exploits will be positively related to its performance.

\section{Valuable resources and dynamic sensing capability}

Dynamic capabilities are a category of resources (Day 2014:27; Kozlenkova, Samaha \& Palmatier 2014:6). A dynamic capability is the firm's potential to systematically solve problems, formed by its propensity to sense opportunities and threats, to make timely decisions, and to implement strategic decisions and changes efficiently to ensure the right direction (Li \& Liu 2014:2794). Dynamic capabilities are the capacity of an organisation to purposefully create, extend or modify its resource base (Helfat et al. 2007:1). Drawing on Teece et al. (1997:516), dynamic capabilities emphasise the importance of coordination, learning, sensing and integrating. It implies that a firm with dynamic capabilities can integrate and redeploy resources, and as a result obtain greater performance. For the purposes of this study, dynamic sensing capability is of interest.

Sensing capability is defined as the ability to spot, interpret, and pursue opportunities in the environment (Pavlou \& El Sawy 2011:243). In franchising, chains must sense the environment to gather market intelligence on market needs, competitor moves, and new technologies in order for managers to identify opportunities. Basic routines of the sensing capability are: generating market intelligence (Galunic \& Rodan 1998:1193), disseminating market intelligence (Kogut \& Zander 1996:76), and responding to market intelligence (Teece 2007:1319). Generating market intelligence relates to identifying customer needs (Teece 2007:1319), being responsive to market trends (Amit \& Schoemaker 1993:33), identifying market opportunities (Day 1994:37), recognising rigidities (Sinkula 1994:35), and detecting resource combinations (Galunic \& Rodan 1998:1193). Disseminating market intelligence relates to interpreting market intelligence (Kogut \& Zander 1996:76), making sense of events and developments, and exploring new opportunities (Teece 2007:1319). Given this logic, it can be concluded that the dynamic sensing capability must be used in combination with resources.

Hence, it can be hypothesised that:

$\mathbf{H}_{2}$ : The valuable resources that a franchise outlet exploits will be positively related to its dynamic capability.

\section{The mediating role of dynamic sensing capability between valuable resources and franchise outlet performance}

Extant literature posits that resources should be transformed into capabilities that help firms get more rents (Chandler \& Steven 1994:331). A capability represents ability to perform a 
coordinated set of tasks utilising organisational resources (Helfat \& Peteraf 2003:999). This is supported by Castanias and Helfat (2001:661) who argue that rents derive not from random or misguided initiatives, but rather from properly motivated and well-directed strategic effort. Dynamic capabilities thus are considered a transformer for converting resources into enhanced performance (Lin \& Wu 2014:411). This implies that if a firm employs resources without dynamic capabilities, it would be operating on misguided initiatives.

Being responsive to market intelligence also relates to initiating plans to capitalise on market intelligence (D'Aveni 1994), and pursuing specific market segments with plans to seize the new market opportunities (Teece 2007:1319). The sensing capability of franchised chains is proposed to enable the reconfiguration of their existing valuable resources. This provides an example to demonstrate how sensing capability positively mediates resources into improved performance. Hence it can be hypothesised that:

$\mathbf{H}_{3}$ : A franchise outlet's dynamic sensing capability will mediate the relationship between its valuable resources and performance.

\section{Methodology}

In order to test the hypotheses of this study, a questionnaire was administered through Qualtrics, and telephone and face-to-face interviews from June 2017 to October 2017.

According to FASA (2016:15), South Africa has over 600 franchised brands and almost 39000 franchised outlets. So the target population of this study comprised franchise outlet managers and owners from the FASA registered member listing (fast food and restaurants; retailing and direct marketing categories) in Gauteng province who had been in franchising since 2014. Researchers used the purposive sampling because the respondents (managers and owneroperators) were chosen according to the managerial level criterion. The selected franchise outlet managers and owneroperators to whom questionnaires were sent were initially 500 from which 224 usable questionnaires were received.

Hypotheses were tested on a representative sample (224 respondents) of active franchisees (owner-operators and managers $)$ in the fast food $(n=128)$ and retailing $(n=96)$ categories in the Gauteng province of South Africa. The franchise category did not influence the results as the findings were aggregated and not split between the different categories of franchises with the emphasis on the mix of resources and capabilities across all franchises. Owner-operators $(n=80)$ and managers $(n=144)$ were taken to be the subject of this study because they must be responsible for firm resources and administering dynamic capabilities.

The questionnaire was emailed to respective outlets through Qualtrics and the interviews were carried out at a franchise outlet where respondents could be easily located. After data cleaning, 224 remained for analysis. From the total, 77 respondents were interviewed by telephone (34.4\%), 53 by
Qualtrics (23.7\%) and 94 face to face (41.9\%). The critical socio-demographic information that was used included the category of franchising, the position in the organisation as well as experience in franchising. Of these 224 respondents, $96(42.9 \%)$ were from the retailing and direct marketing category while $128(57.1 \%)$ were from fast food and restaurants. The majority of respondents who participated were managers $(64.3 \%)$, with owner-operators consisting of just more than a third of respondents (i.e. 35.7\%). The managers are those who are in charge of the resources at the outlets and run or supervise the day-to-day business operations. The respondents were grouped in terms of their experience in franchising. The less experienced (up to 5 years) constituted $89(39.7 \%)$, moderate experience (from 6 years up to 10 years) was $67(29.9 \%)$ and more experienced (from 11 years up to 40 years) amounted to 68 (30.4\%).

\section{Measures}

Questions and items used were established in literature on a seven-point Likert scale. Value items were adapted from Newbert (2008:766) and Perez-Nordtvedt et al. (2008:739). Performance items were adapted from Morgan et al. (2006:627), Newbert (2008:766) and Wilden and Gudergan (2015:190). This meant to explore to what extent valuable resources owned by a franchise outlet affect its performance through dynamic sensing capability. Hence, value with three items was measured based on five different resources as established in Newbert (2008:766). Moreover, performance was measured with four items (sales volume, growth in sales volume, market share and growth in market share). On the other hand, sensing capability was adapted from previous research (Pavlou \& El Sawy 2011:268; Wilden \& Gudergan 2015:190). In order to operationalise this construct, the five items were adapted and adjusted accordingly. They were measured using seven-point Likert scales.

\section{Results}

We applied structural equation modelling with AMOS 24. The model was assessed for internal consistency and the reliability of the applied constructs (Hutter et al. 2013:346). Table 1 displays factor loadings and reliabilities of factors.

All the indicators comprised good factor loadings and Cronbach's alphas were quite high, exceeding the required reliability (Table 1) (Cronbach 1971).

TABLE 1: Summary of factor analysis on five constructs.

\begin{tabular}{lccc}
\hline $\begin{array}{l}\text { Factor or construct and item } \\
\text { description }\end{array}$ & $\begin{array}{c}\text { KMO and } \\
\text { Bartlett's test }\end{array}$ & $\begin{array}{c}\text { \% variance } \\
\text { explained }\end{array}$ & $\begin{array}{c}\text { Cronbach's } \\
\text { alpha }\end{array}$ \\
\hline $\begin{array}{l}\text { Value } \\
\begin{array}{l}\text { My franchise outlet owns resources that } \\
\text { are highly valued in our industry. }\end{array}\end{array}$ & $0.896^{*}$ & 68.484 & 0.914 \\
$\begin{array}{l}\text { Our resources allow my franchise outlet } \\
\text { to exploit market opportunities and } \\
\text { neutralise threats. }\end{array}$ & $0.885^{*}$ & 70.113 & 0.917 \\
$\begin{array}{l}\text { My franchise outlet has the kind of } \\
\text { resources that enable us to conceive of } \\
\text { or implement strategies that improve } \\
\text { its efficiency and effectiveness. }\end{array}$ & $0.884^{*}$ & 77.486 & 0.943 \\
\begin{tabular}{l} 
Performance \\
\hline
\end{tabular} & $0.773^{*}$ & & \\
\hline
\end{tabular}

$*, p<0.000$ 


\section{Model fitness}

The overall causal model was evaluated using multiple fit indices: These included absolute fit index and incremental fit indices. The absolute fit index is the Root Mean Square Error of Approximation (RMSEA). The incremental fit indices are the Tucker-Lewis Coefficient (TLI), Comparative Fit Index (CFI) and Normal Fit Index (NFI). Drawing on structural equation modelling (SEM) that was used for data analysis, an acceptable fit was produced. The indices considered were RMSEA (0.077), TLI (0.8278), CFI (0.8353) and NFI (0.7455). The incremental indices (TLI and CFI) were acceptable because they were between 0.80 and 0.90 (Ullman 1996).

\section{Mediation analysis}

The mediating effect of dynamic sensing capability between valuable resources and performance (sales volume and market share) was explored. First, regressions were run to predict franchise outlet performance from valuable resources predictor. The unstandardised regression coefficients for the prediction of franchise outlet performance from valuable resources predictor (highly valued resources, valuable exploiting resources and valuable efficient resources) were established. It was confirmed that all the independent variables were statistically significant predictors of the dependent variable, $p<0.001$.The results show that valuable resources are significantly related to performance. Hence the first hypothesis is accepted.

Next, the analytical results demonstrate that the valuable resources that a franchise outlet exploits are positively related to its dynamic sensing capability, $p<0.001$. Hence the second hypothesis is supported and accepted. The findings also support the RBV's argument that valuable resources can strengthen the development of dynamic capabilities. This result about the relationship between valuable resources and dynamic sensing capability extends the conclusions from previous studies (Lin \& Wu 2014; Newbert 2008). Hence, when viewed in the context of resource-capability combinations, findings posit that such combinations must be considered first before competitive advantage or performance.

After controlling for the effects of dynamic sensing capability on performance, the effect of valuable resources on performance was no longer significant. Hence the third hypothesis is supported and is accepted. Findings resonate with the RBV idea that accumulating valuable resources and developing dynamic capabilities to mediate resources can enable firms to improve their competitive advantage and thus performance (Teece et al. 1997).

\section{The magnitude of mediated effect}

Drawing on Warner (2013), when variables are measured in meaningful units, it is helpful to think through the magnitude of the effects in real units. The units of measurement have some real-world practical interpretation. Figure 2 guides the practical interpretation.

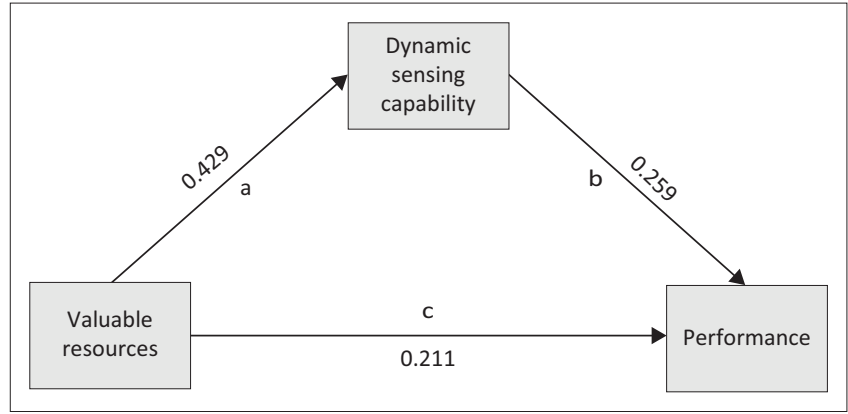

FIGURE 2: Unstandardised path coefficients.

From the first regression analysis the coefficient for the total effect of valuable resources on franchise outlet performance was $c=0.211$. For example, each 1 unit increase in valuable resources can predict an increase in franchise outlet performance of $0.2 \%$. In addition, the assumption that franchisees aim to mobilise valuable resources into a distant future implies significant valuable resource-related increases in franchise outlet performance.

From the second regression, the effect of valuable resources on dynamic sensing capability is $a=0.429$; this was statistically significant. As an illustration, for a 1 unit increase in valuable resources, one can predict almost a $1.5 \%$ increase in dynamic sensing capability. This implies that the more a franchise outlet increases its valuable resources, the more dynamic sensing capability is also required. The final regression provides the two paths, $b$ and $c$. The $b$ coefficient which represents the effect of dynamic sensing capability on franchise outlet performance was $b=0.259$; again it was statistically significant, based on the $t$-test (5.060). For the dynamic sensing capability increase, it predicts almost a $0.3 \%$ increase in franchise outlet performance. Given this logic, franchisees may gain dynamic sensing capability over the long haul, and this would imply dynamic sensing capability is related to increases in franchise outlet performance.

In conclusion, the indirect effect of valuable resources on franchise outlet performance is found by multiplying $a \times b$ (Warner 2013). In this case the product of 0.429 and $0.259=0.111$. This implies that for each 1 unit increase in valuable resources, a $0.11 \%$ increase in performance is predicted through the effects of valuable resources on dynamic sensing capability. On the other hand, the direct effect of valuable resources on performance is still significant. Hence, over and above any dynamic sensing capability-related increases in performance, there is still a substantial increase in performance for each additional valuable resource.

\section{Summary of hypotheses testing}

A compilation of the three research hypotheses is presented in Table 2. The table also indicates that all three of the research hypotheses can hence be accepted. 
TABLE 2: Hypotheses.

\begin{tabular}{ll}
\hline Hypotheses & Result \\
\hline $\begin{array}{l}\mathrm{H}_{1}: \text { The value of resources that a franchise outlet exploits will be } \\
\text { significantly related to its performance. }\end{array}$ & Accepted \\
$\mathrm{H}_{2}:$ The valuable resources that a franchise outlet exploits will be & Accepted \\
significantly related to its dynamic sensing capability. & \\
$\begin{array}{l}\mathrm{H}_{3}: \text { : franchise outlet's dynamic sensing capability will mediate the } \\
\text { relationship between its valuable resources and performance. }\end{array}$ & Accepted \\
\hline
\end{tabular}

\section{Conclusion}

\section{Managerial implications}

The study contributes to the understanding of the RBT as applied in the franchising environment by showing that a definite relationship exists between valuable resources, dynamic capabilities (specifically sensing) and firm performance. The study contributes to the theory by expanding the perspective of the dynamic capabilities (Barney et al. 2011; Teece et al. 1997). It adds additional rigidity to the theory as it proves that the dynamic sensing capability will mediate the relationship between valuable resources and performance. It also adds to the understanding of the relationship between valuable resources and performance by proving that the value of resources that a franchise outlet exploits is significantly related to its performance, and that valuable resources is significantly related to the dynamic sensing capability.

Managers and owner-operators are likely to improve their outlet performance if they own valuable resources in combination with dynamic sensing capability. Franchise owner-operators as well as franchise managers can therefore focus efforts on improving their dynamic sensing capability in conjunction with their valuable resources to increase firm performance. Since the analytical results indicate the importance of valuable resources in developing dynamic sensing capability, franchisees can take a leaf from this study. Physical resources (plant and equipment, geographic location, etc.), financial resources (working capital, cash, etc.), human resources (training, experience, etc. of individual employees), intellectual resources (patents, trademarks, etc.) and organisational resources (relationships with buyers, creditors, etc.) are key for the success of the franchise outlet. Managers whose outlets exploit resources of great value are capable of enjoying high performance, whereas exploited resources may attain low performance if they are of marginal value.

The sensing capability can help managers to identify customer needs, respond to market trends when the industry is affected, identify market opportunities (Day 1994), recognise rigidities (Sinkula 1994), and detect resource combinations (Galunic \& Rodan 1998). Some of these sensing issues are made possible by attending FASA professional activities and conferences. They must continually use established processes to identify target market segments, changing customer needs and customer innovation. Also there is a need to observe the best practices in the sector, such as reengineered menus and recipes in fast foods or merchandising and customer database in retailing.

\section{Limitations and future research}

Drawing on Barney and Mackey's (2005) call to explore RBT using primary data, this study collected primary data from franchisees (managers and owner-operators). Although most franchise outlets use franchisor resources, they are run independently and privately. Hence managers might have felt uncomfortable or uneasy to respond freely without bias. This might have caused response bias although managers were better positioned to respond to questions that deal with resources, dynamic capabilities and performance.

Newbert's (2008) study operationalised the resource-capability combinations as suggested by Penrose (1959), because the argument is to understand and acknowledge the symbiotic relationship that exists among them. Hence this study did not use the VRIN-capabilities combinations. This might have limited the findings that firm's resource-capability combinations result in greater advantage as a result of their exploitation.

Although this study has limitations, they envisage directions for future research opportunities. Structural equation modelling failed to give a perfect or good fit. Hence future research must aim to establish the challenges with VRIN, dynamic capabilities and performance. Secondly, the theoretical underpinnings of RBT propositions and dynamic capabilities are to be explored in other industries with more constructs and items since RBT is criticised for tautology. Franchisees may not be the best population to deal with since most of the resources are franchisor initiated or oriented. Hence, a similar study can be replicated with the franchisors. Another option may be to do a comparative analysis of franchisees and franchisors. Franchise categories were also not distinguished in the results, which could add an additional layer of meaning. This could be explored in future research studies.

Moreover, drawing on Newbert (2008:747) it should be noted that future research must explore independent variables as resource-capability combinations instead of treating them as slices of empirical indicators. Again, the findings in this study also indicate interesting directions for future research in that the model was statistically sound. Hence it can be further tested in large firms where resources and capabilities are idiosyncratic.

\section{Acknowledgements}

Thank you to Dr Marthi Pohl at the University of Pretoria for her guidance and support with the statistical modelling.

\section{Competing interests}

The views expressed in this article are the authors' own and not an official position of the University of Pretoria.

\section{Authors' contributions}

The initial research formed part of a PhD study conducted by Dr Jilson Zimuto under the supervision of Dr Rachel Maritz. Both contributed equally to the development of the article. 


\section{Funding}

This research received no specific grant from any funding agency in the public, commercial, or not-for-profit sectors.

\section{Data availability statement}

Data sharing is not applicable to this article as no new data were created or analysed in this study.

\section{Disclaimer}

The views and opinions expressed in this article are those of the authors and do not necessarily reflect the official policy or position of any affiliated agency of the authors.

\section{References}

Afuah, A., 2013, 'The theoretical rationale for a framework for appraising the profitability potential of a business model innovation', Working paper, Michigan Ross School of Business.

Akremi, A., Perrigot, R. \& Piot-Lepetit, I., 2015, 'Examining the drivers for franchised chains performance through the lens of the dynamic capabilities approach Journal of Small Business Management 53(1), 145-165. https://doi.org/10.1111/ jsbm.12059

Amit, R. \& Schoemaker, P.J.H., 1993, 'Strategic assets and organizational rent', Strategic Management Journal 14(1), 33-46. https://doi.org/10.1002/smj.4250140105

Andersen, J., 2011, 'Strategic resources and firm performance', Management Decision 49(1), 87-98. https://doi.org/10.1108/00251741111094455

Barney, J., 1991, 'Firm resources and sustained competitive advantage', Journal of Management 17(1), 99-120. https://doi.org/10.1177/014920639101700108

Barney, J.B., 1995. 'Looking inside for competitive advantage', Academy of Management Perspectives 9(4), 49-61.

Barney, J.B., Ketchen, D.J. Jr \& Wright, M., 2011. 'The future of resource-based theory: Revitalization or decline?', Journal of Management 37(5), 1299-1315. https://doi. org/10.1177/0149206310391805

Barney, J.B. \& Mackey, T.B., 2005, 'Testing resource-based theory', in D.J. Ketchen \& D.D. Bergh (eds.), Research methodology in strategy and management, pp. 1-13, Elsevier, Greenwich, CT.

Barthélemy, J., 2008, 'Opportunism, knowledge, and the performance of franchise chains', Strategic Management Journal 29, 1451-1463. https://doi.org/10.1002/ smj.719

Bowman, C. \& Ambrosini, V., 2001, 'Value in the resource-based view of the firm A contribution to the debate', Academy of Management Review 26(4), 501-502.

Castanias, R. \& Helfat, C., 2001, 'The managerial rents model: Theory and empirical analysis', Journal of Management 6, 661-678. https://doi.org/10.1177/014920630 102700604

Chandler, G.N. \& Steven, H.H., 1994, 'Market attractiveness, resource-based capabilities, venture strategies, and venture performance', Journal of Business Venturing 9(4), 331-349. https://doi.org/10.1016/0883-9026(94)90011-6

Cohen, J.F. \& Oslen, K., 2013, 'The impact of complementary information technology resources on the service-profit chain and competitive performance of South African hospitality firms', International Journal of Hospitality Management 34, 245-254. https://doi.org/10.1016/j.ijhm.2013.04.005

Combs, J.G. \& Ketchen, D.J., 1999, 'Explaining interfirm cooperation and performance: Toward a reconciliation of predictions from the resource-based view and organizational economics', Strategic Management Journal 20, 867-888. https:// doi.org/10.1002/(SICI)1097-0266(199909)20:9\%3C867::AID-SMJ55\%3E3.0. CO;2-6

Combs, J.G., Ketchen, D.J. Shook, C.L. \& Short, J.C., 2011, 'Antecedents and consequences of franchising: Past accomplishments and future challenges', Journa of Management 37(1), 99-126. https://doi.org/10.1177/0149206310386963

Cronbach, L.J., 1971, 'Test validation', in R.L. Thorndike (ed.), Educational measurement, 2nd edn., pp. 443-507, American Council on Education, Washington, DC.

D'Aveni, R.A., 1994, Hypercompetition: Managing the dynamics of strategic manoeuvring, Free Press, New York.

Davis, D.F. \& Mentzer, J.T., 2008, 'Relational resources in inter-organizational exchange: The effects of trade equity and brand equity', Journal of Retailing 84(4), 435-448. https://doi.org/10.1016/j.jretai.2008.08.002

Day, G.S., 1994, 'The capabilities of market-driven organizations', Journal of Marketing 58(4), 37-52. https://doi.org/10.1177/002224299405800404

Day, G.S., 2014, 'An outside-in approach to resource-based theories', Journal of the Academy of Marketing Science 42, 27-28. https://doi.org/10.1007/s11747-0130348-3

Denrell, J., Fang, C. \& Winter, S.G., 2003, 'The economics of strategic opportunity', Strategic Management Journal 24, 977-990. https://doi.org/10.1002/smj.341
Eisenhardt, K.M. \& Martin, J.A., 2000, 'Dynamic capabilities: What are they?', Strategic Management Journal 21, 1105-1121. https://doi.org/10.1002/1097-0266 (200010/11)21:10/11\%3C1105::AID-SMJ133\%3E3.0.CO;2-E

Franchise Association of South Africa (FASA), 2016, Franchise report, viewed 23 July 2018, from https://www.fasa.co.za/survey.php.

Galunic, D.C. \& Rodan, S., 1998, 'Resource recombinations in the firm: Knowledge structures and the potential for Schumpeterian innovation', Strategic Management Journal 19(12), 1193-1201. https://doi.org/10.1002/(SICI)1097-0266(1998120) 19:12\%3C1193::AID-SMJ5\%3E3.0.CO;2-F

Gemser, G. \& Wijnberg, N.M., 2001, 'Effects of reputational sanctions on the competitive imitation of design innovations', Organization Studies 22, 563-591. https://doi.org/10.1177/0170840601224002

Gillis, W.E., Combs, J.G. \& Ketchen, D.J., 2013, 'Using resource-based theory help explain plural form franchising', Entrepreneurship Theory and Practice 38(3), 449-472. https://doi.org/10.1111/etap.12008

Helfat, C.E., Finkelstein, S., Mitchell, W., Peteraf, M., Singh, H., Teece, D.J. et al., 2007, Dynamic capabilities: Understanding strategic change in organizations, Blackwell, Malden, MA

Helfat, C.E. \& Peteraf, M.A., 2003, 'The dynamic resource-based view: Capability lifecycles', Strategic Management Journal 24, 997-1010. https://doi.org/10.1002/ smj.332

Helfat, C.E. \& Peteraf, M., 2015, 'Managerial cognitive capabilities and the microfoundations of dynamic capabilities', Strategic Management Journal 36 , 831-850. https://doi.org/10.1002/smj.2247

Henderson, R. \& Cockburn, I., 1994, 'Measuring competence? Exploring firm effects in pharmaceutical research', Strategic Management Journal 15, 63-84. https://doi. org/10.1002/smj.4250150906

Holcomb, T.R., Holmes, R.M. \& Connelly, B.L., 2009, 'Making the most of what you have: Managerial ability as a source of resource value creation', Strategic Management Journal 30, 457-485. https://doi.org/10.1002/smj.747

Hutter, K., Hautz, J., Dennhardt, S. \& Fuller, J., 2013, 'The impact of user interactions in social media on brand awareness and purchase intention: The case of MINI on Facebook', Journal of Product \& Brand Management 22(5/6), 342-351. https:// doi.org/10.1108/JPBM-05-2013-0299

Kogut, B. \& Zander, U., 1996, 'What firms do? Coordination, identity, and learning', Organizational Science 7(5), 502-518. https://doi.org/10.1287/orsc.7.5.502

Kozlenkova, I.V., Samaha, S.A. \& Palmatier, R.W., 2014, 'Resource-based theory in marketing', Journal of the Academy of Marketing Science 42, 1-21. https://doi. org/10.1007/s11747-013-0336-7

KPMG, 2016, Annual report 2016, viewed 23 July 2018, from https://home.kpmg. com/uk/en/home/about/annual-report/transparency-report.html.

Lepak, D.P., Smith, K.G. \& Taylor, M.S., 2007, 'Value creation and value capture: A multilevel perspective', Academy of Management Review 32(1), 180-194. https://doi.org/10.5465/amr.2007.23464011

Li, D.Y. \& Liu, J., 2014, 'Dynamic capabilities, environmental dynamism, and competitive advantage: Evidence from China', Journal of Business Research 67, 2793-2799. https://doi.org/10.1016/j.jbusres.2012.08.007

Lin, Y. \& Wu, L., 2014, 'Exploring the role of dynamic capabilities in firm performance under the resource-based view framework', Journal of Business Research 67, 407-413.

Lippman, S.A. \& Rumelt, R.P., 2003, 'The payments perspective: Micro-foundations of resource analysis', Strategic Management Journal 24, 903-927. https://doi. org/10.1002/smj.346

Makadok, R., 2001, 'Toward a synthesis of the resource-based and dynamic-capability views of rent creation', Strategic Management Journal 22, 387-401. https://doi org $/ 10.1002 / \mathrm{smj} .158$

Mol, J.M. \& Wijnberg, N.M., 2011, 'From resources to value and back: Competition between and within organizations', British Journal of Management 22, 77-95. https://doi.org/10.1111/j.1467-8551.2010.00711.x

Morgan, N.A., Vorhies, D.W. \& Schlegelmilch, B.B., 2006, 'Resource-performance relationships in industrial export ventures: The role of resource inimitability and substitutability', Industrial Marketing Management 35, 621-633. https://doi. org/10.1016/j.indmarman.2005.05.018

Mumdziev, N. \& Windsperger, J., 2011, 'The structure of decision rights in franchising networks: A property rights perspective', Entrepreneurship Theory and Practice 35(3), 449-465. https://doi.org/10.1111/j.1540-6520.2011.00440.x

Newbert, S.L., 2008, 'Value, rareness, competitive advantage, and performance: A conceptual-level empirical investigation of the resource-based view of the firm', Strategic Management Journal 29, 745-768. https://doi.org/10.1002/ smj.686

Parmigiani, A. \& Holloway, S.S., 2011, 'Actions speak louder than modes: Antecedents and implications of parent implementation capabilities on business unit performance', Strategic Management Journal 32(5), 457-485. https://doi.org/ 10.1002/smj.920

Pavlou, P.A. \& El Sawy, O.A., 2011, 'Understanding the elusive black box of dynamic capabilities', Decision Sciences 42, 239-273. https://doi.org/10.1111/j.1540-5915. 2010.00287.x

Penrose, E.T., 1959, The theory of the growth of the firm, Wiley, New York.

Perdreau, F., Le Nadant, A. \& Cliquet, G., 2015, 'Human capital intangibles and performance of franchise networks: A complementary view between agency and critical resource perspectives', Managerial and Decision Economics 36, 121-138. https://doi.org/10.1002/mde.2656 
Perez-Nordtvedt, L., Kedia, B.L., Datta, D.K. \& Rasheed, A.A., 2008, 'Effectiveness and efficiency of cross-border knowledge transfer: An empirical examination', Journal efficiency of cross-border knowledge transfer: An empirical examination', Journal
of Management Studies 45(4), 714-744. https://doi.org/10.1111/j.1467-6486. of Management

Perryman, A.A. \& Combs, J.G., 2012, 'Who should own it? An agency-based explanation for multi-outlet ownership and co-location in plural form franchising' Strategic Management Journal 33, 368-386. https://doi.org/10.1002/smj.1947

Peteraf, M.A. \& Barney, J.B., 2003, 'Unravelling the resource-based tangle', Managerial and Decision Economics 24, 309-323. https://doi.org/10.1002/mde.1126

Powell, T.C., 2001, 'Competitive advantage: Logical and philosophical considerations', Strategic Management Journal 22(9), 875-888. https://doi.org/10.1002/smj.173

Priem, R.L., 2007, 'A consumer perspective on value creation', Academy of Management Review 32(1), 219-235. https://doi.org/10.5465/amr.2007.23464055

Santos, F.M. \& Eisenhardt, K.M., 2005, 'Organizational boundaries and theories of organization', Organization Science 16, 491-508. https://doi.org/10.1287/orsc. 1050.0152

Schwarzer, P., 2017, 'World Franchise Council survey on the economic impact of franchising worldwide', Franchise Information Systems, 1-14.

Sinkula, J.M., 1994, 'Market information processing and organizational learning', Journal of Marketing 58, 35-45. https://doi.org/10.1177/002224299405800103

Teece, D.J., 2007, 'Explicating dynamic capabilities: The nature and microfoundations of (sustainable) enterprise performance', Strategic Management Journal 28(13) 1319-1350. https://doi.org/10.1002/smj.640

Teece, D.J., Pisano, G. \& Shuen, A., 1997, 'Dynamic capabilities and strategic management', Strategic Management Journal 18(7), 509-533. https://doi.org/ 10.1002/(SICI)1097-0266(199708)18:7\%3C509::AID-SMJ882\%3E3.0.CO;2-Z
Ullman, S.E., 1996, 'Social reactions, coping strategies, and self-blame attributions in adjustment to sexual assault', Psychology of Women Quarterly 20, 505-526. https://doi.org/10.1111/j.1471-6402.1996.tb00319.x

Warner, R.M., 2013, Applied statistics: From bivariate through multivariate techniques, 2nd edn., Sage, Thousand Oaks, CA.

Watson, A., Stanworth, J., Healeas, S., Purdy, D. \& Stanworth, C., 2005, 'Retail franchising: An intellectual capital perspective', Journal of Retailing and Consumer Services 12(1), 25-34. https://doi.org/10.1016/j.jretconser.2004.02.001

Wernerfelt, B., 1984, 'A resource-based view of the firm', Strategic Management Journal 5, 171-180. https://doi.org/10.1002/smj.4250050207

Wexler, M.N., 2002, 'Organisational memory and intellectual capital', Journal of Intellectual Capital 3(4), 393-414. https://doi.org/10.1108/14691930210 448314

Wilden, R. \& Gudergan, S.P., 2015, 'The impact of dynamic capabilities on operational marketing and technological capabilities: Investigating the role of environmental turbulence', Journal of the Academic Marketing Science 43, 181-199. https://doi. org/10.1007/s11747-014-0380-y

Wingrove, C.A. \& Urban, B., 2017, 'Franchised fast food brands: An empirical study of factors influencing growth', Acta Commercii-Independent Research Journal in the Management Sciences 17(1), 1-8. https://doi.org/10.4102/ac.v17i1.431

Yin, X. \& Zajac, E.J., 2004, 'The strategy/governance structure fit relationship: Theory and evidence in franchising arrangements', Strategic Management Journal 25, 365-383. https://doi.org/10.1002/smj.389

Zollo, M. \& Winter, S.G., 2002, 'Deliberate learning and the evolution of dynamic capabilities', Organization Science 13(3), 339-351. https://doi.org/10.1287/orsc. 13.3.339.2780 